University of Florida Levin College of Law

UF Law Scholarship Repository

UF Law Faculty Publications

Faculty Scholarship

5-1999

\title{
"Driving While Black": Corollary Phenomena and Collateral Consequences
}

Katheryn Russell-Brown

University of Florida Levin College of Law, russellbrown@law.ufl.edu

Follow this and additional works at: https://scholarship.law.ufl.edu/facultypub

Part of the Civil Rights and Discrimination Commons, and the Law Enforcement and Corrections Commons

Recommended Citation

Katheryn Russell-Brown, "Driving While Black": Corollary Phenomena and Collateral Consequences, 40 B.C. L. Rev. 717 (1999), available at http://scholarship.law.ufl.edu/facultypub/230

This Article is brought to you for free and open access by the Faculty Scholarship at UF Law Scholarship Repository. It has been accepted for inclusion in UF Law Faculty Publications by an authorized administrator of UF Law Scholarship Repository. For more information, please contact kaleita@law.ufl.edu. 


\title{
"DRIVING WHILE BLACK": COROLLARY PHENOMENA AND COLLATERAL CONSEQUENCES
}

\author{
KATHERYN K. RUSSELL*
}

\section{Introduction: Statement of the Problem}

In the public arena, issues of race continue to command center stage. ${ }^{1}$ The ongoing debates and discussions have raised new questions, while not necessarily answering the old ones. Specifically, the recent dialogues have focused on the role that Blackness plays in today's society. Some assign Blackness a primary role, others believe it is secondary. Still others dismiss it as tertiary. These varied positions, ranging from "race has nothing to do with this" to "race has everything to do with this" have in some ways canceled out any meaningful discussion of racial issues. Each of the racial camps has been allowed to claim victory without giving any ground. The result: racial homeostasis.

This failure of movement is particularly troubling given that in the legal arena, Blackness itself faces increasing criminal penalty-both actual and perceived. One of the clearest examples is the phenomenon of "Driving While Black" ("DWB"). This expression has been used to describe a wide range of race-based suspicion of Black and Brown motorists. ${ }^{2}$

* Associate Professor, Criminology \& Criminal Justice Department, University of Maryland at College Park. A.B., 1983, University of California at Berkeley; J.D., 1986, Hastings Law School; Ph.D., 1992, University of Maryland. The author thanks Professors Bernadette W. Hartfield and Ellen Podgor for the invitation to participate in this symposium.

1 One salient example is President Clinton's 1997 initiative on race. See President's InItiative on Race, One America in the 21st Century: The President's Initiative on Race (1998). Another is the public debate following publication of Richard J. Herrnstein and Charles Murray's book, The Bel. Curve: Intelligence and Class Structure in AMerican Life (1994).

2 DWB has also been used to indicate "Driving While Brown"-the racial profiling of Hispanic motorists. Blacks and Hispanics, however, are not the only minorities who report being subjected to traffic stops on the basis of race. See, e.g., Leslie Marmon Silko, Yellow Woman aNd a BEAUTY OF The SpIrit: Essays on Native AMerican Life Today 107-23 (1996) (describing the Immigration and Naturalization Service Border Patrol's detention and harassment of Native American motorists).

Racial profiling could be the result of an express police department policy, for example, where police department memoranda identify a particular racial group as part of its drug courier profile. It could also be the result of an informal, implied policy in which race is relied upon to 
Once an offense known and discussed almost exclusively among African-Americans, DWB has risen from relative obscurity. Several factors are responsible for this. First, the United States Supreme Court decided Whren $v$. United States, involving a Fourth Amendment challenge to possible racial profiling in routine traffic stops. ${ }^{3}$ The Whren Court held that earlier Supreme Court decisions "foreclose any argument that the constitutional reasonableness of traffic stops depends on the actual motivations of the individual officers involved." The Whren decision thus made clear that, in the Court's eyes, traffic stops motivated by the racial prejudices of individual officers do not violate the Fourth Amendment's search and seizure guarantees, at least when there are other reasons for the stop. ${ }^{5}$

Second, during the same time period the Court issued this decision, there have been several high-profile incidents involving allegations of racial profiling. The case of Robert Wilkins, a Black attorney, is among the most notable. ${ }^{6}$ Wilkins was traveling with family members, returning home from a funeral. Their car was stopped by a Maryland State Police officer and detained along a Maryland interstate road. The officer told the driver (Mr. Wilkins' cousin) he had been speeding and then requested consent to search the vehicle. After consent was refused, the officers forced the occupants to wait until a narcotics dog was summoned to sniff the vehicle for drugs. No drugs were found

determine whether stops are made. See infra notes 8-9 and accompanying text (discussing practices of New Jersey State Troopers). Racial profiling might also be the result of an individual officer's practices, based on stereotypes and prior experiences.

${ }^{3} 116$ S. Ct. 1769, 1772-73 (1996); see also Maryland v. Wilson, 117 S. Ct. 882 (1997) (regarding police conduct during routine traffic stops); Ohio v. Robinette, 117 S. Ct. 417 (1996) (same).

Though the U.S. Supreme Court has not expressly used the term "Driving While Black," it has appeared in decisions by lower courts. See, e.g., Washington v. Lambert, 98 F.3d 1181, 1188 (9th Cir. 1996) ('There's a moving violation that many African-Americans know as D.W.B.: Driving While Black." (quoting Henry L. Gates, Jr., Thirteen Ways of Looking at a Black Man, NEw YoRkER, Oct. 23, 1995, at 59)).

${ }^{4} 116$ S. Ct. at 1774.

${ }^{5}$ The Court did note, however, that selective enforcement of the law based upon race could be challenged under the Equal Protection Clause. See id. For detailed discussion and aunalyses of the Whren decision, see Angela J. Davis, Race, Cops, and Traffic Stops, 51 U. Miam L. Rev. 425, 432-38 (1997); David A. Harris, Car Wars: The Fourth Amendment's Death on the Hightuay, 66 Geo. WASH. L. Rev. 556 (1998); Carl J. Schifferle, After Whren v. United States: Applying the Equal Protection Clause to Racially Discriminatory Enforcement of the Law, 2 Mrch. L. \& PoL'y Rev. 159 (1997); David A. Sklansky, Traffic Stops, Ninority Motorists, and the Future of the Fourth Amendment, 1997 Sur. Cr. Rev. 271, 277-79 (1998); Craig M. Glantz, Note, "Could" This Be the End of Fourth Amendment Protections for Motorists?: Whren v. United States, 116 S.Ct. 1769 (1996), 87 J. Cks L. \& CRIminology 864 (1997); Jennifer A. Larrabee, Note, "DWB (Driving While Black)" and Equal Protection: The Realities of an Unconstitutional Police Practice, 6 J.L. \& PoL'Y 291 (1997).

${ }^{6}$ See, e.g., Melba Newsome, Potver: The Usual Suspects, Vire, Sept. 1998, at 109. 
and, almost one hour after they had been pulled over, the Wilkins family was allowed to continue on their journey. Following the incident, Wilkins filed a federal lawsuit, alleging constitutional and civil rights violations resulting from racial profiling practices by Maryland State Troopers. ${ }^{7}$

Another case involved a police shooting along the New Jersey Turnpike. ${ }^{8}$ Four young men, three Black and one Hispanic, were traveling south on their way to a basketball camp. New Jersey state troopers stopped the van due to excessive speed. The police said that as they approached the vehicle from the rear it moved into reverse. The troopers responded with several rounds of gunfire, striking the van and its occupants 11 times. $^{9}$

Third, in response to the Supreme Court's rollbacks and the escalating number of well-publicized race-based traffic stops, Congressman John Conyers introduced the "Traffic Stops Statistics Act." 1997 bill did not make it through Congress. In April of 1999, however, Conyers introduced an updated version of the earlier legislation. ${ }^{11}$ The newer version has several additions, including a requirement that police collect data on gender and record whether the immigration status of occupants was questioned. The earlier bill was successful in placing

7 The eventual settlement of the Wilkins case involved monetary damages and injunctive relief. See Davis, supra note 5 , at 440 . As Davis relates:

The Maryland State Police consented to adopt a policy prohibiting the use of race-based drug courier profiles as a law enforcement tool. They further agreed that the policy would direct all Maryland State Police not to use a race-based profile as a cause for stopping, detaining or searching motorists traveling on Maryland roadways.

Id. (citing Settlement Agreement, Wilkins v. Maryland State Police, United States District Court for the District of Maryland, Civil Action No. MJG-93-468). For an interesting analysis of the Wilkins case and discussion of related issues, see Davis, supra note 5, at 438-42.

${ }^{8}$ See Jolın Kifner \& David M. Herszenhorn, Racial 'Profiling' at Crux of Inquiry Into Shooting by Troopers, N.Y. Times, May 8, 1998, at B1. For an overview and critique of racial profiling on the New Jersey Turnpike, see Jolnn Lamberth, Driving While Black; A Statistician Proves that Prejudice Still Rules the Road, WASH. PosT, Aug. 16, 1998, at C1.

${ }^{9}$ During the past year, the New Jersey Attorney General's office investigated traffic stops made by 164 New Jersey Troopers. Investigators discovered that some troopers routinely falsified the race of the drivers they stopped. Further, the investigation revealed the practice of "ghosting." Some troopers may have used this scheme to hide the fact that they were targeting minority drivers for traffic stops. "Two state police supervisors said it was common practice for troopers on the turnpike to jot down the license plate number of white motorists who were not stopped and use them on the reports of blacks who were pulled over." David Kocieniewski, Trenton Charges 2 Troopers with Faking Drivers' Race, N.Y. TIMEs, Apr. 20, 1999, at A23.

10 See H.R. 118, 105th Cong. (1997); see also Kevin Merida, Decriminalizing Driving While Black, 'EMERGE, Dec.Jan. 1999, at 26 (noting John Conyers' introduction of the bill and discussing the bill's provisions); infra notes 35-14 and accompanying text.

11 See Traffic Stops Statistics Study Act of 1999, H.R. 1443, 106th Cong. (1999). 
a spotlight on the problem of racially-motivated traffic stops. The American Civil Liberties Union, for example, initiated a national campaign which highlighted DWB. It ran notices in national publications, including the New York Times and Emerge magazine. ${ }^{12}$ The ad copy read, "Let me ask you something . . . Should 'Driving While Black' be a crime?" It also encouraged support for the Conyers bill. ${ }^{13}$

Finally, journalists have given increasing air-time to DWB. ${ }^{14}$ As the number of DWB stories has increased, so has the number of DWB stories involving Black celebrities. ${ }^{15}$ In turn, this media coverage prompted the call for stepped-up measures to address DWB.

The prevalence of DWB is unknown. Determining its breadth, however, is particularly important as a sociological phenomenon, given the role that cars play in American life. ${ }^{16}$ This is particularly true for Blacks who have a historically unique relationship with their cars. During the era of Jim Crow, separate and unequal laws and racial discrimination by white business owners meant that Blacks could not secure hotel accommodations or eat in public restaurants. ${ }^{17}$ This forced many of those Blacks driving long distances to sleep and eat in their cars.

The fact that the expression "DWB" has become commonplace is both heartening and depressing. The DWB short-hand indicates that

\footnotetext{
12 See, e.g., EMERGE, Dec.Jan. 1998, at 31.
}

${ }^{13}$ The notice also includes the ACLU website, (http://wwvaclu.org/forms/trafficstops.html) and encourages readers to complete a complaint form. See $i d$.

14 See, e.g., Timothy Egan, On Wealthy Island, Being Black Means Being a Police Suspect, N.Y. Times, May 10, 1998, at 12; Michael A. Fletcher, Driven to Extremes; Black Men Take Steps to Avoid Police Stops, Wash. Post, Mar. 29, 1996, at A1; Newsome, supra note 6; Hart Scely, Blacli Males Say Its Normal for Police to Find an Excuse to Stop Their Cars and Hunt for Drugs, SYracusE Heratd AMr., Oct. 22, 1995, at A12.

${ }^{15}$ A short roll call of names of well-known Black men, who have been subject to "DWB," include: Marcus Allen, Le Var Burton, Calvin Butts, Johnnie Cochran, Christopher Darden, Miles Davis, Michael Eric Dyson, Al Joyner, Wynton Marsalis, Joe Morgan, Walter Mosley, Edwin Moses, Will Smith, Wesley Snipes, Blair Underwood, Cornel West, Jamaal Wilkes, Roger Wilkins and William Julius Wilson. See, e.g., Katheryn K. Russell, The Color of Crime: Racial Hoaxes, White fear, Black Protectionism, Police Harassment, and Other Macronggressions 36 (1998).

For many Blacks, including the author, stories of DWB are part of family lore. As a child, I heard stories about racially-motivated traffic stops. One incident, involving my father's brother stands out. My uncle, who at the time drove a Lambourghini-a distinctive, rare sports car-was stopped by police. The officer informed him that there had been a report of a stolen vehicle fitting his car's description. My uncle asked him the make of the stolen velicle. The officer, apparently not sure what type of car my uncle was driving, could not answer.

${ }^{16}$ See, e.g., Harris, supra note 5, at 576 ("[N]o activity is common to more Americans than driving or riding in a car.").

${ }^{17}$ See, e.g., Katzenbach v. McClung, 379 U.S. 294 (1964); Heart of Atlanta Motel, Inc. v. United States, 379 U.S. 241 (1964). 
this form of racial profiling has entered the public's vocabulary. Can it be a good sign that a questionable police practice is so firmly entrenched that it earns an acronym? The very fact that DWB has become so widespread that it has an acronym may mean that it has become an acceptable practice-the acronym makes DWB appear routine, normal and inevitable.

This Article explores DWB and related phenomena. Further, it considers how these problems affect criminal justice processing in particular and social policy in general. The discussion is divided into three parts. The first part considers ways in which Blackness has become a standard indicator of criminality. The second part provides an overview of the 1997 Traffic Stops Statistics Act. The final part evaluates the social fallout of DWB and its collateral consequences.

\section{Corollary Phenomena: DWB's Kin}

In recent years, there has been mounting evidence that Blackness has become an acceptable "risk factor" for criminal behavior. ${ }^{18}$ In all facets of life, Blacks report being stigmatized and labeled based on their race. As several high profile cases make clear, this labeling can have wide-ranging-even deadly-consequences. These cases point to the problem of determining what role race plays in interactions with law enforcement. At the same time, however, these examples indicate that in some instances the perception that race matters means that race matters. Further, individual cases can be explained, dismissed and justified. In their aggregate, the stream of anecdotal cases which suggest that Blackness can be equated with criminality has social consequences. A few examples follow. ${ }^{19}$

\section{A. Walking While Black}

Paul Butler, a Black professor in Washington, D.C., describes his experience of being stopped, questioned and hassled by police, as he

\footnotetext{
${ }^{18}$ For an interesting discussion of the historical and contemporary link between Blackness and criminality, see Tracey Maclin, Race and the Fourth Amendment, 51 VAND. L. REv. 333, 333-36 (1998). Professor Maclin observes that "[t]oday, police departments across the nation . . . continue to target blacks in a manner reminiscent of the slave patrols of colonial America." Id. at 336; see also Charshee C.L. Mcintyre, Criminalizing a Race: Free Blacks During Slavery $167-88$ (1993).

${ }^{19}$ It is noted that while most of the DWB incidents referenced in this Article involve Black males, Black females also report being subject to race-based traffic stops. See Russelu, supra note 15, at 36 (describing Black astronaut Mae Jemison's brush with police); infra note 28 (summarizing Lubbock, Texas incident involving Hampton University basketball coaches, Patricia Bibbs and Vanetta Kelso).
} 
returned home by foot one evening. ${ }^{20}$ Butler details his ongoing "discussion" with Metropolitan Police officers, who insisted that he show them identification before being allowed to continue on his way. Butler stood his ground, and the officers left only after a neighbor identified him.

\section{B. Idling While Black}

In December of 1998, Tyisha Miller, a nineteen-year-old Black woman, was shot and killed by Riverside, California police after they responded to a call. ${ }^{21}$ Miller's car had a bad tire late one night and she stayed with the car, parked at a gas station, while her friend got a ricle home and called Miller's family. As her friend left, Miller rolled up the windows, turned up the car's heat and radio and tipped her seat back. When Miller's cousin and a friend arrived at the gas station to help, the cousin found Miller locked in the car, foaming from the mouth and unresponsive to shouts and banging on the window. A gun was in Miller's lap.

The friend called 911 to summon police help, reporting they could not wake Miller and that she had a gun in her lap. When the police arrived, Miller's cousin told them that Miller was in medical distress and again mentioned the gun. The police responded by breaking Miller's car window and shooting inside. Miller was struck twelve times in the head and back.

Police initially claimed that Miller shot at them and they simply returned fire. The four officers involved subsequently backed away from their initial story, and the police found no evidence that Miller had fired the gun. One of the more unsettling aspects of the case has been that, for many Blacks, it underscores the paradoxical threat of the police. Some even blame Miller's cousin for her death, claiming "You killed her! You called 911!"22

${ }^{20}$ See Paul Butler; 'Walking While Black': Encounters with the Police on My Street, LeGal TIMES, Nov. 10, 1997, at 23.

${ }^{21}$ See William Booth, Calif. Police Shooting, Veiled in Gray, Becomes Black-White Isstte, WAs11. Post, Jan. 10, 1999, at A3; Don Terry, Unanswered Questions in a Fatal Police Shooting, N.Y. TIMEs, Jan. 9, 1999, at A8. The U.S. Attorney's office has announced that it will initiate an inquiry into whether Miller's civil rights were violated. See U.S. to Investigate Killing of Teen-Ager, N.Y. TIMES, Jan. 5, 1999, at A13.

${ }_{22}$ Terry, supra note 21, at A8. 


\section{Standing While Black}

This is the name Professor David Cole gives to the "crime" created by the ordinance at issue in City of Chicago v. Morales. ${ }^{23}$ The controversial Chicago ordinance makes it a crime for gang members, or anyone who associates with them, to stand on a public street with no discernible purpose. It empowers police to stop anyone they "reasonabl[y] believe to be a criminal street gang member loitering in any public place with one or more other persons." ${ }^{24}$ The Morales court observed that the vagueness of such an ordinance does not discourage arbitrary or discriminatory enforcement. ${ }^{25}$ The ordinance is eerily reminiscent of a Georgia slave code statute which stated, "Any person who sees more than seven men slaves without any white person, in a high road, may whip each slave twenty lashes." ${ }^{26}$

\section{Shopping While Black}

In a widely-reported 1995 incident, three young Black men, shopping at a suburban Washington, D.C. Eddie Bauer store, reported being harassed and embarrassed. ${ }^{27}$ An off-duty police officer, moonlighting as a store security officer, suspected that one of the youths, Alonzo Jackson, had stolen a shirt from the store. The youth, when questioned, told store employees that he had purchased the shirt at that store the previous day. His story was not considered credible and he was told he would have to remove the shirt he was wearing before he would be allowed to leave the store. The three youths filed a federal civil rights lawsuit against Eddie Bauer, alleging "consumer racism." After finding that the young men had been falsely imprisoned and defamed and that Eddie Bauer negligently supervised its security guards, the jury awarded $\$ 1$ million in damages. ${ }^{28}$

${ }^{23}$ See David Cole, 'Standing While Black,' The Nation, Jan. 4, 1999, at 24. See generally' Chicago, Ill., Municipal Code § 8-4-015 (added June 17, 1992), available in <http://wwww-chicityclerk.com/legislation/codes/chapter8_4.html>; City of Chicago v. Morales, 687 N.E.2d 53 (IIl. 1997). For a discussion of the ordinance, see Cole, supra.

${ }^{24}$ Chicago, ILl., Municipal CODE $\$ 8-4-015$. The ordinance carries up to a $\$ 500$ fine, six months imprisonment and 120 hours of community service. See id.

25 See Morales, 687 N.E.2d at 63.

${ }^{26}$ J. Clay Smith, Jr., Justice and Jurisprudence and the Black Lauyer, 69 NOTrE DAME L. REv. 1077, 1109 (1994) (quoting Georgia's Act of Dec. 13, 1792).

${ }^{27}$ See, e.g., Joann Loviglio, Eddie Bauer Discrimination Case Goes to Jury in Greenbelt Court, DAILY REC. (Baltimore), Oct. 8, 1997, at 19.

${ }^{28}$ See, e.g., Joann Loviglio, Civil Rights Not Violated, But Eddie Bauer Told to Pay $\$ 1$ Million in Shoplifing Case, Legal. INTELligencer, Oct. 10, 1997, at 4 (Alonzo Jackson was awarded $\$ 850,000$ and the other young men awarded $\$ 75,000$ apiece). 


\section{E. ... While Black}

There are numerous other miscellaneous offenses which fall under the "While Black" umbrella. One example is "bus riding while Black." One such incident involved John Gainer, a Black music professor at the University of Oregon. Based on a grainy enlarged photo of a different man suspected in a motel robbery, a mall security guard mistook Gainer for the robbery suspect and called the police. Police boarded the city bus Gainer was leaving on and asked him to exit the bus to answer questions. Soon after Gainer left the bus, however, police discovered the mistake. This was the second time in two years that police pulled Gainer off a city bus to question him about crimes he did not commit. The first time, after a series of mail thefts, a bystander saw Gainer closely scrütinizing mailbox numbers and called the police. Gainer, who is legally blind, told the police he was simply looking for a house to rent. ${ }^{29}$

The above anecdotes exemplify the extent to which society allows Blackness to be equated with criminality. Further, it is noted that there are numerous other ways in which Blackness has been targeted and criminalized, such as legislation enacted explicitly to address what is perceived as Black deviance. ${ }^{30}$ Although some might argue that race-

There have been other court cases which have alleged consumer racism. See, e.g., Steven A. Holmes, Large Damage Award to Black Whom Store Sicspected of Theft, N.Y. Times, Dec. 11, 1997, at $\mathrm{Al} 7$ (citing case finding Dillard's department store engaged in systematic discrimination against Black customers, with federal jury awarding plaintiff Paula Hampton $\$ 1.56$ million). Anecdotal incidents of racial discrimination while shopping abound. See, e.g., Patricia J. Wit. liams, The Alchenty of Rage and Rights $44-47$ (1991).

In a recent case, two Black Hampton University basketball coaches were stopped and detained by police, in Lubbock, Texas. The coaches, in town for a game against Texas Tech, wcre arrested and charged with running a confidence game. It was later determined that the two had been mistakenly suspected. See Mark Asher, Hampton Coach Decries Being Falsely Accused, 'WAsn. Post, Nov. 19, 1998, at E1.

${ }^{20}$ See Black Professor Mistaken for Robbery Suspect-Again, Associated Press, Dec. 29, 1998; $c$. How about some common sense?, THE BuLlETIN (Bend, Or:), Jan. 6, 1999, at A6 (editorial recounting these repeated mistaken police apprehensions of Gainer but arguing racism was not involved). For more examples of how Blackness has been used as indicia of criminality, sec DAvid CoLE, No Equal Justice: Race and Class in the American Criminal Justice Systen 16-62 (1999).

30 See, e.g., Dorothy Roberts, KIlling the Black Body: RACE, Reproduction, ANd tIIE MEANING OF LiBERTy 150-201 (1997). Roberts offers an incisive critique of how laws lave been used to criminalize Black reproduction. The federal crack statute, which punishes possession of crack one hundred times more severely than powder cocaine, is another example of a law enacted partly due to racial fears. The bill was passed partly in response to the wide-spread fear that inner-city crack and its problems would spread to the suburbs. For a detailed discussion of the historical relationship between race and federal drug laws, see United States v. Clary, 846 F. Supp. 768 (E.D. Mo. 1994), rev'd, 34 F.3d 709 (8th Cir. 1994). 
based police practices simply reflect crime rates, this view raises as many questions as it answers. ${ }^{31}$

A review of American history indicates that equating Blackness with criminality has long been a profitable enterprise. Professor Frederick Dennis Greene provides an interesting analysis of the parallels between the economics of the U.S. slave trade and today's prison system, as evidenced by the explosion in incarceration and prison construction. ${ }^{32}$ In this mushrooming incarceration, Blacks are six times more likely than whites to be held in jail or prison. ${ }^{33}$ This incarceration suggests that DWB and other "While Black" offenses are part of a much larger social problem. ${ }^{34}$

Mountains of anecdotes from the rich, famous and otherwise, have not resulted in a tangible, productive response to the problem of DWB. In order to move the debate beyond anecdote and personal narrative, it is clear that something more is needed. Enactment of the Traffic Stops Statistics Act has the potential to further transform the debate from an individual, micro-level issue, to a societal, macro-level concern. The next section details and critiques this legislative response to DWB.

${ }^{91}$ The argument is that Blacks are more likely to arouse police suspicion because Blacks are more likely to commit street crime. It is true that Blacks are disproportionately more likely to engage in street crime. Their rates of criminal involvement, however, do not approximate their encounters with the police. While Blacks are responsible for approximately one-third of all street crime, studies indicate that nearly half report having been watched or stopped by the police when they have done nothing wrong. See, e.g., Sandra Lee Browning et al., Race and Getting Hassled by the Police, 17 Police Stud. 1, 3, 6 (1994) (finding that about $47 \%$ of Blacks and $10 \%$ of whites surveyed report being "personally hassled" by police; $66 \%$ of Blacks and $12.5 \%$ of whites report "vicarious hassling" by police (knowing someone who has been hassled by police)).

${ }^{32}$ See Frederick Dennis Greene, Immigrants in Chains: Afrophobia in American Legal HistoryThe Harlem Debates Part 3, 76 OR. L. Rev. 537, 562-65 (1997). Notably, increases in incarceration and prison construction are occurring despite the fact that since 1980 the total crime rate has generally decreased. See Sourcebook of Criminal Justice Statistics-1997, at 261 tbl.3.111, 285 tbl.3.120 (Kathleen Maguire \& Ann L. Pastore eds., 1998).

${ }^{93}$ See Fox Butterfield, Number of Inmates Reaches Record 1.8 Million, N.Y. Trmes, Mar. 15, 1999, at A12 (Blacks six times more likely than whites to be held in jail and now make up over $40 \%$ of inmate population).

${ }^{34}$ Professor Derrick Bell has argued that racial progress for Blacks is more likely to take place if the relief serves "the best interests of the country." DERRICK BELL, RACE, RACISM AND AMERICAN LAw 12 (3d ed. 1992). In other words, such progress is more likely if the relief benefits more than just Black people. 


\section{Ray of Light?: The Traffic Stops Statistics Act ${ }^{35}$}

For almost two years, the proposed Traffic Stops Statistics Act ("the Act"), offered a beacon of hope for altering the racial landscape of routine traffic stops. ${ }^{36}$ The 1997 Act and its updated version would require record-keeping for each traffic stop. An officer who pulled over a motorist would have had to record an array of data for each traffic stop, including the race and age of the person stopped, whether a - search was conducted and whether it produced contraband, whether a citation or ticket was issued and the legal basis for the stop. ${ }^{37}$

Not surprisingly, the proposed legislation and its state-level counterparts $^{38}$ have sparked a good bit of controversy and support. Police unions, for instance, have raised two main objections. First, such a law would place an undue burden on an already overworked police force. Second, such legislation would reverse years of police training designed to discourage officers from "seeing" race. The International

${ }^{35}$ H.R. 118, 105th Cong. (1997); see also H.R. ReP. No. 105-435 (1998), available in 1998 WL 105467 (discussing a later version of the bill). The version of the bill that passed the House in 1998 was known as the Traffic Stops Statistics Study Act of 1998.

${ }^{36}$ Draft notes following the original Conyers bill state:

No American should have to live with the constant fear of an unwarranted pullover: African-Americans across the country are familiar with the offense of "DWB," driving while Black. There are virtually no African-American males-including Congressmen, actors, athletes and office workers-who have not been stopped at one time or another for an alleged traffic violation, then harassed with questions and searches. They may not receive tickets, but they do receive humiliation and more reason to distrust the justice system.

(notes on file with author).

37 See H.R. 118.

${ }^{38}$ Several states and jurisdictions have taken up this issue. For example, in California, A.B. 1264, a bill introduced by State Representative Kevin Murray, would have required annual record-keeping through the year 2003. See California Traffic Stops Statistics Act, A.B, 1264, 1997-98 Regular Sess. (Cal. 1997); see also Doc Anthony Anderson, III, They're guilly of driving while being black or browm, SAN DIEgo UNION-TriBunE, Dec. 24, 1998, at B7 (discussing origins of the bill). In contrast to the federal bill, A.B. 1264 explicitly mandated recording the gender of the person stopped. See generally S. Comi. on Pub. Safety, Committe Rep. for 1997 Cal. Assembly Bill No. 1264, 1997-98 Regular Sess. (Cal. 1998), available in Westlaw CGA Database (discussing features of California bill). In 1998, then-Governor Pete Wilson vetoed the bill. See Anderson, supra.

In April of 1999, the North Carolina legislature gave final approval to a bill which would mandate data collection for routine traffic stops. See The State Requires Study of Highway Patrol Stops; N.C. House approves 'driving while black' bill, Morning STAR (Wilmington, N.C.), Apr. 8, 1999, at 3B. Rhode Island has similar legislation pending. See Traffic Stops Statistics Act of 1998, S. 98-2434, Jan. Sess. (R.I. 1998). In addition, in at least two cities, San Jose and San Diego, California, law enforcement officials are voluntarily keeping race-based statistics on traffic stops. Julie N. Lynem \& Marshall Wilson, When Police Stop People for 'Driving While Black'; Cities move to track who is getting pulled over, SAN Francisco Chronicle, Apr: 7, 1999, at Al. 
Association of Chiefs of Police, the largest organization of police executives, opposes any such legislation. ${ }^{39}$ The National Organization of Black Law Enforcement Executives, however, has voiced support for the Conyers legislation. ${ }^{40}$

Aside from objections raised by law enforcement, the bill's wording was problematic and its approach too narrow. First, it did not require any data about the police officer (e.g., age, race). Second, it would not have provided information on the location of traffic stops (e.g., city, state). As a result, the data could not be used to discern possible trends in DWB stops. Furthermore, the collected data were only to be used for research or data collection; the data would not be available for litigation purposes.

The failure to pass either federal or state legislation-or adopt . other measures in their place-that would provide a picture of the role of race and traffic stops, leaves us where we started. The law's failure to respond proactively to the documented problem of DWB has several consequences. For one, the absence of a way to measure the breadth and scope of the practice forces reliance on anecdotes and lawsuits. As a result, a great deal of what has been learned about racial profiling in traffic stops has been filtered through civil actions, such as Robert Wilkins' case. ${ }^{41}$

The settlement in Wilkins revealed the degree to which Maryland State Troopers target Black motorists. ${ }^{42}$ The terms of the settlement mandated the maintenance of computer records for all motorist stops. Along the Interstate 95 corridor, Black motorists, who comprise about seventeen percent of motorists, comprised more than seventy percent of the people stopped by the Maryland State Troopers between 1995 and 1997.43 Amazingly, the racial imbalance in traffic stops persisted even after Troopers were notified that their stops were being monitored. ${ }^{44}$

The singling out of minority motorists represents an egregious, identifiable harm. There are, however, other, subtler outcomes which may sprout from these practices. The next section considers the possible fallout from society's failure to rein in DWB and DWB-related incidents.

\footnotetext{
${ }^{39}$ See Kevin Jolnnson \& Gary Fields, Police chiefs resist race-related tallies, USA ToDAy, Apr. 8, 1999 , at $7 \mathrm{~A}$.

${ }^{40}$ See $i d$.

41 See supra notes 6-7 and accompanying text.

42 See supra note 7; see also RuSSELL, supra note 15, at 40-43; Lamberth, supra note 8.

43 See Russell, supra note 15 , at $41-42$.

${ }^{44}$ This result raises the issue of what the impact of a bill such as the Traffic Stops Statistics
} 


\section{Collateral Consequences of Fallure to Agt}

This Article has argued that DWB is part of a larger phenomenon which increasingly criminalizes Blackness. There are several potential outcomes from our continued failure to respond to the increased equating of Blackness with criminality. Two recent examples follow.

\section{A. Legal Circumvention}

In United States v. Leviner, ${ }^{45}$ Federal District Judge Nancy Gertner issued a downward departure in the federal sentencing guidelines. ${ }^{16}$ The reasoning behind the downward departure makes this otherwise unremarkable case remarkable. Alexander Leviner had several prior convictions before the subject of the case-being a felon in possession of a handgun. Under the guidelines, Leviner's criminal history classified him as a "Category V" offender, the second highest category. ${ }^{47}$ After reviewing the record, Judge Gertner made two observations. First, that Leviner was Black. Second, she pointed out that most of his prior convictions were for motor vehicle offenses ${ }^{48}$ These factors led Judge Gertner to conclude that Leviner's priors were likely a result of DWB stops:

Motor vehicle offenses in particular, raise deep concerns about racial disparity. Studies from a number of scholars, and articles in the popular literature have focused on the fact that African American motorists are stopped and prosecuted for traffic stops, more than any other citizens. And if that is so, then it is not unreasonable to believe that African Americans would also be imprisoned at a higher rate for these offenses, as well. 49

It is unclear whether other judges have taken action similar to Gertner. It is known, however, that in other contexts federal judges

Act would be. If the Wilkins case is any guide, the institution of a Conyers-like bill would do little to deter racial profiling, at least in the short-term.

${ }^{45}$ Criminal No. 97-10260-NG, 1998 U.S. Dist. LEXIS 20323 (D. Mass. Dec. 22, 1998).

${ }^{46}$ This decision has been widely reported. See, e.g., Fox Butterfield, Bias Cited in Reducing Sentence of Black Man, N.Y. Trares, Dec. 17, 1998, at A22; David Cole, Driving While Black: Curbing race-based traffic stops, WASH. PosT, Dec. 28, 1998, at $A 25$.

47 See Leviner, 1998 U.S. Dist. LEXIS 20323, at $* 25$. Category VI is the highest criminal history category under the Sentencing Guidelines. See id. Scores 10-12 are in category V. See $i d$. at *25 n.17. Leviner's total score was 11. See id. at $* 25$.

48 See id. at *26-28.

$49 \mathrm{Id}$. at $* 33-34$ (citations omitted). Judge Gertner sentenced Leviner to a 30-month term. See id. at $* 38$. 
have sought relief from harsh, racially disparate laws. The response of some federal judges to the federal crack statute provides one such example. Indeed, more than a few federal judges have balked at the disparity between crack and powder cocaine sentences and at their racially disparate impact. ${ }^{50}$ Some judges have resigned in protest, ${ }^{51}$ while others have apologized to defendants in advance of sentencing. ${ }^{52}$

\section{B. Public Policy Fallout}

A recent case involving the National Urban League illustrates another negative consequence of failing to address the DWB issue. In the fall of 1998, the Urban League withdrew from the Clinton Administration's "Buckle Up America" campaign. ${ }^{53}$ The drive, which would make failure to wear a safety belt a primary traffic offense, would allow police officers to stop and ticket motorists for neglecting to do so. Citing concerns and fears that such a practice would result in increased racial profiling of Blacks, the Urban League withdrew its support.

The Urban League's response, though understandable, is problematic. This is especially true given that young Black and Hispanic motorists are twice as likely as their white counterparts to die in crashes due to failure to wear seat belts. ${ }^{54}$ Furthermore, the failure to address the problem of seat belt use in Black and Hispanic communities increases the probability of not only higher mortality rates, but also increased auto insurance premiums and hospital costs for crash-related injuries. The Urban League's response indicates that the problem of DWB extends beyond the criminal justice system and impacts support for social policies. This stance has the potential for creating as much harm as it seeks to prevent. The Urban League's position symbolizes the tension between Blacks and the law enforcement community.

50 See RuSSELL, supra note 15 , at 133 \& 188 n.6.

51 See id.

52 See, e.g., Judge Is Forced to Lengthen Sentences for Crack, N.Y. Times, Nov. 27, 1995, at B5 ("[Judge Lyle Strom] who has bucked Federal sentencing guidelines in crack cocaine cases, arguing that they discriminate against blacks, reluctantly obeyed a higher court's instructions last week and used those guidelines to sentence two brothers. But in issuing the sentence [he] ... apologized and told the brothers he would continue working to soften the guidelines.").

${ }^{53}$ See Warren Brown, Urban League Quits Seat Belt Drive; Group Cites Fears of Increased Police Harassment of Minorities, WASH. Post, Dec. 11, 1998, at A14.

${ }^{54}$ See id. 


\section{Other Responses}

In addition to legal circumvention and public policy fallout, the DWB problem undoubtedly has additional ramifications. Moreover, the overarching issue of equating Blackness with deviance has a wide range of social costs. These include racial hoaxes, ${ }^{55}$ anti-Black conspiracies, ${ }^{56}$ lack of trust between police and Black and Hispanic communities and a more general racial alienation. ${ }^{57}$

\section{CONCLUSION}

This Article provides a brief overview of various ways that Blackness has been criminalized and associated with deviance. The discussion has primarily centered on DWB, and the host of legal, social and empirical questions raised by this recent phenomenon. It is argued that although DWB is among the most well-known crimes of Blackness, it is hardly the only one of its kind. In fact, the net which criminalizes Blackness has been cast far and wide.

It is, therefore, not surprising that the societal consequences of failing to address DWB and related phenomena, are grave indeed. The association of crime and deviance triggers a predictable cycle of events. First, it increases the probability that Blacks will be targeted for arrest. This in turn increases the probability that Blacks will be convicted and incarcerated for crimes. ${ }^{58}$ Following logically, the enhanced likelihood of a felony conviction increases the likelihood of disenfranchisement. ${ }^{59}$

\footnotetext{
${ }^{55}$ See RuSSELL, supra note 15, at 69-93.

${ }^{56}$ See, e.g., id. at 145-46; Regina Austin, Beyond Black Demons $\mathcal{E}$ White Devils: Anti-Black Conspiracy Theorizing \& the Black Public Sphere, 22 FLA. ST. U. L. REv. 1021 (1995). See generally patricia A. Turner, I Heard it Through the Grapevine: Rumor in African-American CuLTURE (1993).

${ }^{57}$ See, e.g., Vincene Verdun, The Only Lonely Remedy, 59 OHIO ST. L.J. 793, 794 (1998) ("I put all [the racial slights] in [my] gunnysack, then and every time since then, until the sack got full. I threw all the hurt that comes from being black into the gunnysack, and then I moved on. But now, the gunnysack is full and heavy, and I sometimes get really tired of carrying it around. . . . You see, once the sack is full, any new weight that is picked up must be put somewhere clse, so it is stored in the heart, the mind, the kidneys, or somewhere." (emphasis added)); see also RusseLL, supra note 15 , at $138-48$.

${ }^{58}$ Increasing incarceration of Blacks seems likely despite the fact that crime is on the decline. See generally Fox Butterfield, Inmates Serving More Time, Justice Department Reports, N.Y. Times, Jan. 11, 1999, at A10 (quoting observation of Frank Zimring, director of the Earl Warren Legal Institute at University of California at Berkeley, that "the changes in the American prison population are the result of a shift in policy, rather than any basic change in the nature of criminals or the crime rate"); Butterfield, supra note 33 (number of inmates at record ligh though crime rates have dropped for seven consecutive years; Blacks six times more likely than whites to be held in jail).

${ }^{59}$ See generally The Sentencing Project \& Human Rights Watch, Losing the Vote: The Impact of Felony Disenfranchisement Laivs in the United States (1998). This report
} 
Further, a felony conviction increases social marginality in many tangible ways, such as circumscribing employment possibilities (thereby increasing the probability of re-offending).

The impact of this goes far beyond those particular African Americans who have directly experienced racial targeting. As discussed above, it affects Blacks as a group and alters their response to the criminal justice system. As important, however, is the fact that criminalizing Blackness taints the image that every other racial groupwhites, American Indians, Asians and Hispanics-have of Blacks. These images, which have historically materialized into racially-skewed criminal justice policy, regenerate the cycle.

indicates that $13 \%$ of Black men (1.4 million) are disenfianchised due to criminal conviction for certain types of crimes. See id. at 1 . Black men represent more than one-third $(36 \%)$ of all persons ineligible to vote due to a felony conviction. See id. 
HeinOnline -- 40 B.C. L. Rev. 732 1998-1999 